\title{
THE INFLUENCES OF FISCAL DECENTRALIZATION ON ECONOMIC PERFORMANCE: EMPIRICAL EVIDENCE FROM OECD COUNTRIES
}

\section{Fuhmei Wang*}

\begin{abstract}
Based on OECD country experiences over the period from 1990 to 2015, this research rigorously investigates: (1) how fiscal autonomy effects economic growth; (2) whether there is an optimal level of decentralization; and (3) whether and how other factors influence economic performance in a decentralized economy. We find that revenue decentralization does not affect economic performance. The expenditure decentralization dividend in terms of an enhanced economic growth rate can be achieved only when the initial share of local government expenditure is smaller than the growth-maximizing degree through along with tax collection and trade openness.
\end{abstract}

Keywords: decentralization dividend, economic growth, OECD country experiences JEL Classification: C33, H77, O47

\section{Introduction}

Due to various political-economic concerns, decentralization has led many subnational governments to increase spending in order to achieve their policies and signal competence, in accordance with their constituents' demands. Moving towards greater fiscal decentralization is a recent phenomenon in many advanced countries, such as Australia, Germany and Switzerland (Tanzi, 1996; Litvack, Ahmad, and Bird, 1998; Freitag and Vatter, 2008). The literature defines fiscal decentralization in a number of different ways. The current study defines expenditure (revenue) decentralization as a ratio of sub-federal spending to total public spending (revenue) (Zhang and Zou, 1998; Iimi, 2005; Davoodi and Zou, 1998; Lin and Liu, 2000; Chu and Yang, 2012; Baskaran, Feld, and Schnellenbach, 2016). With decentralization, regional governments gain more autonomy in the provision and financing of public goods. Residents then move across jurisdictions according to levies on income and properties as well as their demands for consumption and investment. All jurisdictions thus have capacities to provide comparable levels of public services, such as public infrastructure and social security programmes. Decentralization improves the efficiency of providing public services and attracts investment, which can stimulate economic growth (Tiebout, 1956; ThieBen 2003; Akai and Sakata, 2002; Brueckner, 2006). Nevertheless,

* Fuhmei Wang, Department of Economics and Department of Public Health, National Cheng Kung University, Tainan, Taiwan (fmwang@mail.ncku.edu.tw).

This work was supported by Grants from the Ministry of Science and Technology of Taiwan (Grant Nos. MOST 103-2410-H-006-086-, MOST104-2410-H-006-109 -, and MOST105-

2410-H-006-091). The funder had no role in study design, data collection and analysis, decision to publish, or preparation of the manuscript. 
decentralization decreases economies of scale in the production of public goods by reducing jurisdiction sizes (Oates, 1972; Gehlbach, 2007). Furthermore, bureaucratic corruption is closely related to governance autonomy when public officials have direct responsibility for tax collection and the provision of public services or application of specific regulations (Rose-Ackerman, 1975; Prud'homme, 1995; Mauro, 1995; Tanzi, 1996; Myerson, 2006). The distribution of resources between jurisdictions might lead to rents being extracted from offices, reduce investment in the private sector, and deter economic growth. Can better economic performance be achieved through greater decentralization? The findings of the current literature with regard to the influences of fiscal decentralization on economic growth are ambiguous (Thornton, 2007; Chu and Yang, 2012; Baskaran, Feld, and Schnellenbach, 2016), and this is one motivation for the current study.

How much public expenditure and revenue should be allocated to subnational governments? Although theoretical studies of fiscal federalism have simulated several ways through which decentralization in non-productive public spending could effect economic growth, previous research might not suggest the optimal level of fiscal decentralization using empirical evidence (Chu and Yang, 2012). Based on the Organization for Economic Cooperation and Development (OECD) country experiences, this research thus aims to investigate whether raising sub-federal government autonomy can effectively improve economic performance, and so it also endeavours to find the optimal level of decentralization to maximize economic growth. This study undertakes rigorous scientific examinations to examine the following issues: (1) how fiscal autonomy effects economic growth; (2) whether there is an optimal level of decentralization; and (3) whether and how other factors influence economic performance in a decentralized economy. The results could be used to derive the appropriate degree of decentralization to obtain better economic performance.

The rest of this study proceeds as follows. Section 2 establishes the theoretical model and derives the equilibrium outcomes of the economy. Section 3 provides empirical estimations to quantitatively assess the growth effects of fiscal decentralization. Section 4 then concludes this work.

\section{The Analytical Framework}

Consider an economy with no population growth. Agents gain utilities from private consumption and publicly-purchased goods. The representative household possesses the following discounted sum of future instantaneous utilities:

$$
U=\int_{0}^{\infty} e^{-\delta t}\left[\log C_{t}+\eta \log G_{e t}\right] d t \quad \eta>0 .
$$

Parameter $\delta$ is the instantaneous time preference rate and parameter $\eta$ presents the positive impact of consumption on public goods $G_{e t}$ on utilities. In the following derivation, time scripts have been dropped for simplicity.

Barro (1990) sets up an endogenous growth model with the flow specification of government expenditure. Productive government expenditure complements private capital in production. Capital is the only input in production and can be a composite of physical 
and human capital, as Rebelo (1991) indicates. The production function is in Cobb-Douglas form, and thus capital and the public infrastructure expenditure are imperfect substitutes. The household producer possesses the following production technology:

$$
y=A k^{\alpha}\left[\varphi_{1} G_{I}\right]^{\beta}\left[\left(1-\varphi_{1}\right) G_{I}\right]^{\omega} \quad 0<\phi<1,
$$

in which $A$ is the technological parameter, while $\alpha, \beta$, and $\omega$ represent the elasticities of real output with respect to per capita capital stock, $k$, sub-federal productive spending, $\phi_{1} G_{I}$, and central government spending, $\left(1-\phi_{1}\right) G_{I}$, respectively. Parameter $\phi_{1}$ is the fraction of subfederal spending to total public spending. The degree of expenditure decentralization increases with the value of this parameter. All producers are symmetric, which implies that they set the same price and output in equilibrium. The goods market is one with perfect competition. The production function is concave with constant returns to scale, and this ensures that the maximization problem is well defined.

Government expenditures are financed contemporarily by income taxes, with a flat tax rate, $\tau$ :

$$
G=G_{e}+G_{I}=\theta G+(1-\theta) G=\phi_{2} \tau y+\left(1-\phi_{2}\right) \tau y,
$$

in which $\theta$ and $1-\theta$, respectively, denote the fractions of government consumption expenditure, $G_{e}$, and infrastructure expenditure, $G_{I}$, to total public spending. Parameter $\phi_{2}$ represents the fraction of sub-federal revenue over total public revenue. Disposable income that is not currently consumed becomes capital accumulation:

$$
\dot{k}=(1-\tau) y-C .
$$

Rearranging the government budget constraint, Equation 3, together with the production function, Equation 2, generate:

$$
\frac{G}{k}=\left[A \tau \phi_{1}^{\beta}\left(1-\phi_{1}\right)^{\omega} \theta^{1-\alpha}\right]^{\frac{1}{\alpha}} .
$$

Based on the Pontryagin's maximum principle, the dynamics of this macroeconomic equilibrium are composed of Equations 6 and 7, respectively, presenting the evolution of consumption and the transversality conditions:

$$
\begin{gathered}
\frac{\dot{C}}{C}=\gamma=\alpha(1-\tau) A^{\frac{1}{\alpha}} \varphi_{1}^{\frac{\beta}{\alpha}}\left(1-\varphi_{1}\right)^{\frac{\omega}{\alpha}} \tau^{\frac{1-\alpha}{\alpha}}-\delta . \\
\lim _{t \rightarrow \infty} \lambda(t) k(t)=0 .
\end{gathered}
$$

Equation 6 reveals that the economic growth rate is a function of the tax rate, $\tau$, the degree of expenditure decentralization, $\phi_{1}$, the contribution of private capital to output, $\alpha$, and the contributions of sub-federal and central infrastructure provided to output, $\beta$ and $\omega$. Equation 7 is the transversality condition, which restricts $k$ from growing too fast. Maximizing Equation 6 with respect to $\phi_{1}$ and taking into account the best infrastructure provision between central and local governments yield the following:

$$
\frac{\partial \gamma}{\partial \phi_{1}}=\alpha(1-\tau) A^{\frac{1}{\alpha}} \tau^{\frac{1-\alpha}{\alpha}}\left[\frac{\beta}{\alpha} \phi_{1}^{\frac{\beta-\alpha}{\alpha}}\left(1-\phi_{1}\right)^{\frac{\omega}{\alpha}}-\frac{\omega}{\alpha} \phi_{1}^{\frac{\beta}{\alpha}}\left(1-\phi_{1}\right)^{\frac{\omega-\alpha}{\alpha}}\right]_{<}^{>} 0 .
$$


Equation 8 indicates that an increase in the degree of decentralization has ambiguous effects on the equilibrium growth rate. The key factors for this result are how the contribution of subfederal infrastructure provision on production, $\beta$, interacts with that of central government on production, $\omega$. A rise in the degree of decentralization affects economic performance through two channels. The first is the fiscal resources crowding out effect, whereby an increase in sub-federal productive expenditure reduces central government's productive expenditure, as Equation 3 shows. This channel tends to deteriorate the productivity in an economy, as Equation 2 shows. The second is the effects of productivity improvement, whereby an increase in sub-federal spending has positive effects on private productivity and leads to better economic performance. The net effect of a rise in the degree of decentralization on economic growth depends upon the relative strength of these two channels. Obviously, a rise in the degree of expenditure decentralization favours (deters) the balanced growth rate if it improves (deteriorates) private productivities. The revenue decentralization does not affect the productivity in the private sector and the economic growth rate, as Equation 6 shows.

From Equation 8, we can find a critical value of $\phi_{1}$, namely $\phi_{1}{ }^{*}$, which maximizes the balanced growth rate:

$$
\phi_{1}^{*}=\frac{\beta}{\beta+\omega} .
$$

Equation 9 implies that in order to maximize economic growth, the optimal fraction of subfederal spending over total public spending could be set at the ratio of the contribution of subfederal productive spending to the production, $\beta$, to the contribution of total public productive spending to the production, $\beta+\omega$. At first expenditure decentralization improves productive capacity; then, after the critical ratio is reached, the growth effects become negative as the sub-federal government expands and the central government contracts. The influence of expenditure decentralization on economic growth is thus nonlinear and concave. The decentralization dividend in terms of an enhanced economic growth rate can be achieved only when the initial degree of decentralization is smaller than the growthmaximizing one.

\section{Empirical Analysis}

\subsection{Econometric specification}

Existing studies (Davoodi and Zou, 1998; ThieBen, 2003; Martinze-Vazquez and McNab, 2006; Ge et al., 2016; Baskaran, Feld and Schnellenbach, 2016) have examined various aspects of the decentralization-economic growth nexus. However, the historical and institutional backgrounds of each country are unique, and thus the question is a rather complex one. An empirical methodology which controls for cross-country variations in certain political and economic institutional characteristics, and successfully deals with differences across countries, would be able to offer a better framework for statistical inferences. If income were also a function of government spending, the use of simple Ordinary Least Squares (OLS) estimation would lead to biased and inconsistent parameter 
estimates due to regressor endogeneity. This paper introduces the Generalized Methods of Moments (GMM) technique to derive the design of the estimators of interest with independent variables that are correlated with past and possibly current realizations of the error (Blundell and Bond, 1998; Baum, Schaffer, and Stillman, 2007).

The actual workings of decentralized systems in developing countries are just beginning to emerge, and thus it might not effectively address these countries' experiences with the available data. The well-established fiscal decentralized systems in developed countries have contributed to improvements in sub-federal autonomy, although this could also have ambiguous effects on economic performance. OECD countries could be regarded as the representative of developed nations. Based on Equation 6, the econometric specifications are presented as follows:

$$
\begin{gathered}
\log y_{i t}=\omega_{1} \log y_{i t-1}+\omega_{2} \phi_{i t}+\omega_{3} \phi_{i t}{ }^{2}+\omega_{4} X_{i t}+\eta_{i t}+\delta_{t}+\varepsilon_{i t} \\
t=1,2, \ldots, T ; \quad i=1,2, \ldots, N
\end{gathered}
$$

where $\log y_{i t}$ represents per capita real GDP in logarithmic form (based on 2010 US dollars), $\varphi_{i t}$ represents the fraction of sub-federal revenue or expenditure over total public revenue and expenditure, $\eta_{i}$ represents a country-specific effect, $\delta_{t}$ represents a time-year effect, $\varepsilon_{i t}$ represents an idiosyncratic error term, and $i$ and $t$ represent country and time period, respectively. The variable $X_{i t}$ is composed of the growth rate of population (Levine and Renelt, 1992), growth rate of private capital (Mullen and Williams, 1994), different tax structures (Branson and Lovell, 2001), transparency indexes (Mauro, 1995), government debt ratios (Verdier, 2008), openness (Edwards, 1993), and the components of government spending. The influence which each type of government expenditure has on productivity and growth has been of particular interest in the literature (Turnovsky and Fischer, 1995). According to the classifications used by the International Monetary Fund, expenditures on military, education, and health care are classified as productive expenditure, while those on goods, services, and social security are classified as consumption expenditures. Government spending variables then include the ratios of the aforementioned government expenditures to real GDP.

To eliminate the country-specific effects, since the OLS technique is known to produce biased results in a dataset with a small time dimension taking the first-differences on Equation 10 yields:

$$
\log y_{i t}-\log y_{i t-1}=\xi_{1}\left(\log y_{i t-1}-\log y_{i t-2}\right)+\xi_{2} \Delta \phi_{i t}+\xi_{3} \Delta \phi_{i t}^{2}+\xi_{4} \Delta X_{i t}+\xi_{5} \Delta \delta_{i t}+\xi_{6} \Delta \varepsilon_{i t} .
$$

Because the econometric settings are based on first differences, problems stemming from possible non-stationarity are avoided. This approach gives us confidence in the reported coefficients and standard errors.

\subsection{Data sources}

This study uses a yearly panel dataset over the period from 1990 to 2015 to investigate the decentralization-growth nexus for 33 OECD countries. These countries are Australia, Austria, Belgium, Canada, Chile, the Czech Republic, Denmark, Finland, France, Germany, 
Greece, Hungary, Iceland, Ireland, Israel, Italy, Japan, South Korea, Luxembourg, Mexico, the Netherlands, New Zealand, Norway, Poland, Portugal, the Slovak Republic, Slovenia, Spain, Sweden, Switzerland, Turkey, the United Kingdom and the United States. All data, except for the transparency indexes, which are collected from Transparency International, come from the World Development Indicators online. Table 1 presents the statistics of the variables. According to these, this study has relatively large ranges of values since the estimated samples are more comprehensive. In our sample, the top three countries with the highest real GDP per capita are Luxembourg (US\$110,001), Norway (US\$91,593), and Switzerland (US\$75,800); Poland has the lowest real GDP per capita, with US\$5,510. In addition, Canada and Sweden, respectively, have the highest degrees of expenditure decentralization, at 65.90 per cent, and revenue decentralization, at 36.92 per cent, whereas the lowest decentralization on expenditure and revenue are in the Slovak Republic at 5.17 per cent and Greece at 0.75 per cent, respectively.

Table 1 | Summarized Statistics of Focal Variables over the Period from 1990 to 2015 for OECD Countries

\begin{tabular}{|l|r|r|r|r|}
\hline Variables & Mean & Maximum & Minimum & Std. Dev. \\
\hline $\begin{array}{l}\text { Per capita GDP } \\
\text { (US dollars in 2010) }\end{array}$ & $35,200.31$ & $110,001.1$ & $5,510.63$ & $20,106.16$ \\
\hline Per capita GDP growth rate (\%) & 1.84 & 25.64 & -11.40 & 2.93 \\
\hline Population growth rate (\%) & 0.69 & 6.02 & -1.69 & 0.67 \\
\hline $\begin{array}{l}\text { Government consumption expenditure } \\
\text { share of GDP (\%) }\end{array}$ & 18.85 & 30.00 & 8.38 & 4.12 \\
\hline Military expenditure share of GDP (\%) & 1.94 & 17.69 & 0.12 & 1.52 \\
\hline Education expenditure share of GDP(\%) & 4.70 & 8.28 & 1.88 & 1.27 \\
\hline Health care expenditure share of GDP (\%) & 5.88 & 10.05 & 1.36 & 1.70 \\
\hline Investment growth rate(\%) & 2.80 & 35.72 & -50.91 & 8.42 \\
\hline Inflation rate (\%) & 5.05 & 137.97 & -5.26 & 10.46 \\
\hline Government debt share of GDP (\%) & 44.76 & 177.98 & 0.82 & 29.50 \\
\hline Decentralization degree in expenditure (\%) & 25.35 & 65.90 & 5.17 & 13.29 \\
\hline Decentralization degree in revenue (\%) & 10.99 & 36.92 & 0.75 & 8.36 \\
\hline Corruption index & 6.99 & 10.00 & 2.23 & 1.88 \\
\hline Tax rates (\%) & 33.49 & 49.58 & 10.98 & 7.91 \\
\hline Tax structure & 1.07 & 3.27 & 0.27 & 0.54 \\
\hline Trade Openness & 81.86 & 391.50 & 15.92 & 50.9 \\
\hline Dummy for developing status & 0.82 & 1.00 & 0.00 & 0.39 \\
\hline
\end{tabular}

Note: Std. Dev. is standard deviation.

Source: Own calculation 


\subsection{Empirical results}

Table 2 presents the empirical results of influences of decentralization and focal variables on economic growth for 33 countries as a whole. The statistics for the Sargan and Hansen tests are 0.51 and 0.89 indicating that the variables we select are valid. The statistics of the AR (1) and AR (2) tests are 0.08 and 0.45 , and indicate that first- and second-order serial correlations do not exist among the residuals.

Based on the index of expenditure decentralization, the coefficient of $\left(\log y_{i t-1}-\log y_{i t-2}\right)$ is significant, positive and smaller than 1. Persistent economic growth thus holds. The influences of government expenditure on the provision of education and health care on economic growth are positive yet insignificant. This result is in contrast to those reported in Canning and Fay (1993) and Levine and Renelt (1992), but consistent with that in Devarajan, Vinoya, and Zou (1996). The negative impact of government consumption expenditure on economic growth is in line with that found in previous research (Easterly and Rebelo, 1993). The estimated coefficients of population growth, military devotion, the inflation rate, government transparency, and government debt are insignificant, suggesting that economic growth may not be influenced by these factors. The level of developing positively affects economic performance, and this may be because more developed countries generally have better established infrastructure in different regions, thus attracting more investment for economic development. This study finds that the ratio of tax revenue to GDP positively effects economic growth, which contradicts the conventional wisdom. This paper measures the index of tax structure as the ratio of the indirect tax revenue to the direct tax revenue (Branson and Lovell, 2001). Collecting more revenue from indirect taxation than from income insignificantly leads to better economic performance.

A decentralized government will under-provide productive public goods which directly benefit residents and should choose income taxes for financing to stimulate economic growth (Hatfield, 2015). Because income accrues to the current generation, taxing it relives the tax burden on the future generation, and leaves them with more income out of which to save, and the net effect on capital accumulation and economic growth is positive (Uhlig and Yanagawa, 1996). Trade openness along with appropriate decentralization are associated with faster economic growth. Economic integration gives rises to agglomeration and specialization effects at the regions. Subnational governments demand more autonomy power for providing public good to compete for internationally mobile factors (Krugman, 1991; Stegarescu, 2009).

Our primary interest is how decentralization affects economic growth. Based on Equation 11, apart from the degree of expenditure decentralization, the significant explanatory variables are averaged using a constant term, and the effects of expenditure decentralization on economic growth are estimated as follows:

$$
\text { Economic growth rate }=1.8+0.02 \phi_{1}-0.00022 \phi_{1}{ }^{2} .
$$

Differentiating Equation 12, we find the optimal share of sub-federal spending to the whole public spending is $45.46 \%$ with economic growth rate at $2.25 \%$; the real share is $25.35 \%$ with the economic growth rate at $2.17 \%$. 
Table 2 | Estimation Results for the GMM Regression of the Full Sample

\begin{tabular}{|c|c|c|c|c|}
\hline \multirow{2}{*}{$\begin{array}{l}\log y_{i t}-\log y_{i t-1} \\
\text { Constant }\end{array}$} & \multicolumn{2}{|c|}{$\begin{array}{c}\text { Degree } \\
\text { of decentralization } \\
\text { in expenditure }\end{array}$} & \multicolumn{2}{|c|}{$\begin{array}{c}\text { Degree } \\
\text { of decentralization } \\
\text { in revenue }\end{array}$} \\
\hline & 0.92 & $(0.34)$ & 0.98 & $(0.76)$ \\
\hline $\log y_{i t-1}-\log y_{i t-2}$ & $0.88^{* * *}$ & $(0.05)$ & $0.92^{* * *}$ & $(0.08)$ \\
\hline Population growth rate (\%) & 0.02 & $(0.02)$ & 0.05 & $(0.02)$ \\
\hline Government consumption expenditure share of GDP (\%) & $-0.0004^{* *}$ & $(0.00)$ & -0.01 & $(0.01)$ \\
\hline Military expenditure share of GDP (\%) & -0.01 & $(0.01)$ & -0.01 & $(0.04)$ \\
\hline Education expenditure share of GDP (\%) & 0.00 & $(0.00)$ & 0.01 & $(0.01)$ \\
\hline Health care expenditure share of GDP (\%) & 0.02 & $(0.01)$ & $0.02^{* *}$ & $(0.02)$ \\
\hline Investment growth rate (\%) & $0.003^{* *}$ & $(0.00)$ & $0.003^{* *}$ & $(0.00)$ \\
\hline Inflation rate (\%) & 0.00 & $(0.00)$ & 0.00 & $(0.00)$ \\
\hline Government debt share of GDP (\%) & 0.00 & $(0.00)$ & 0.00 & $(0.00)$ \\
\hline Decentralization degree in expenditure (\%) & $0.02^{* *}$ & $(0.01)$ & - & \\
\hline Square of Decentralization degree in expenditure (\%) & $-0.00022^{* *}$ & $(0.00)$ & - & \\
\hline Decentralization degree in revenue (\%) & - & & -0.02 & $(0.01)$ \\
\hline Square of Decentralization degree in revenue (\%) & - & & 0.00 & $(0.00)$ \\
\hline Corruption index & 0.01 & $(0.01)$ & 0.00 & $(0.00)$ \\
\hline Tax rates (\%) & $0.0004^{* *}$ & $(0.00)$ & 0.001 & $(0.00)$ \\
\hline Tax structure & 0.03 & $(0.03)$ & 0.00 & $(0.04)$ \\
\hline Trade Openness & $0.001^{* *}$ & $(0.00)$ & $0.00^{*}$ & $(0.00)$ \\
\hline Dummy for developing status & $0.15^{*}$ & $(0.07)$ & $0.1^{*}$ & $(0.07)$ \\
\hline First-order autocorrelation test ( $p$-value) & & 0.08 & & 0.07 \\
\hline Second-order autocorrelation test ( $p$-value) & & 0.45 & & 0.19 \\
\hline Sargan test ( $p$-value) & & 0.51 & & 0.11 \\
\hline Hansen test ( $p$-value) & & 0.89 & & 0.79 \\
\hline
\end{tabular}

Note: ${ }^{* * *} p<0.01,{ }^{* *} p<0.05,{ }^{*} p<0.1$. The numbers in parentheses are standard errors.

Source: Own estimation

Figure 1 presents the inverse U-shaped relationship between the degrees of expenditure decentralization and economic growth rates. A nonlinear relationship exists between expenditure decentralization and economic growth, which is consistent with previous findings (ThieBen, 2003). With full centralization or decentralization, economies have economic growth rates of $1.8 \%$ and $1.82 \%$, respectively. Though ThieBen (2003) used the OLS (ordinary least square) estimation method and tested 26 high-income OECD countries over 
the period from 1973 to 1998 to verify the existence of the nonlinear decentralization-growth nexus, the exact optimal level of expenditure decentralization was not discussed. However, the current research finds that an optimal level of decentralization for maximizing economic growth in OECD countries does exist, and may not have been noticed in earlier works.

Figure 1 | The Relationship between Expenditure Decentralization and Economic Growth

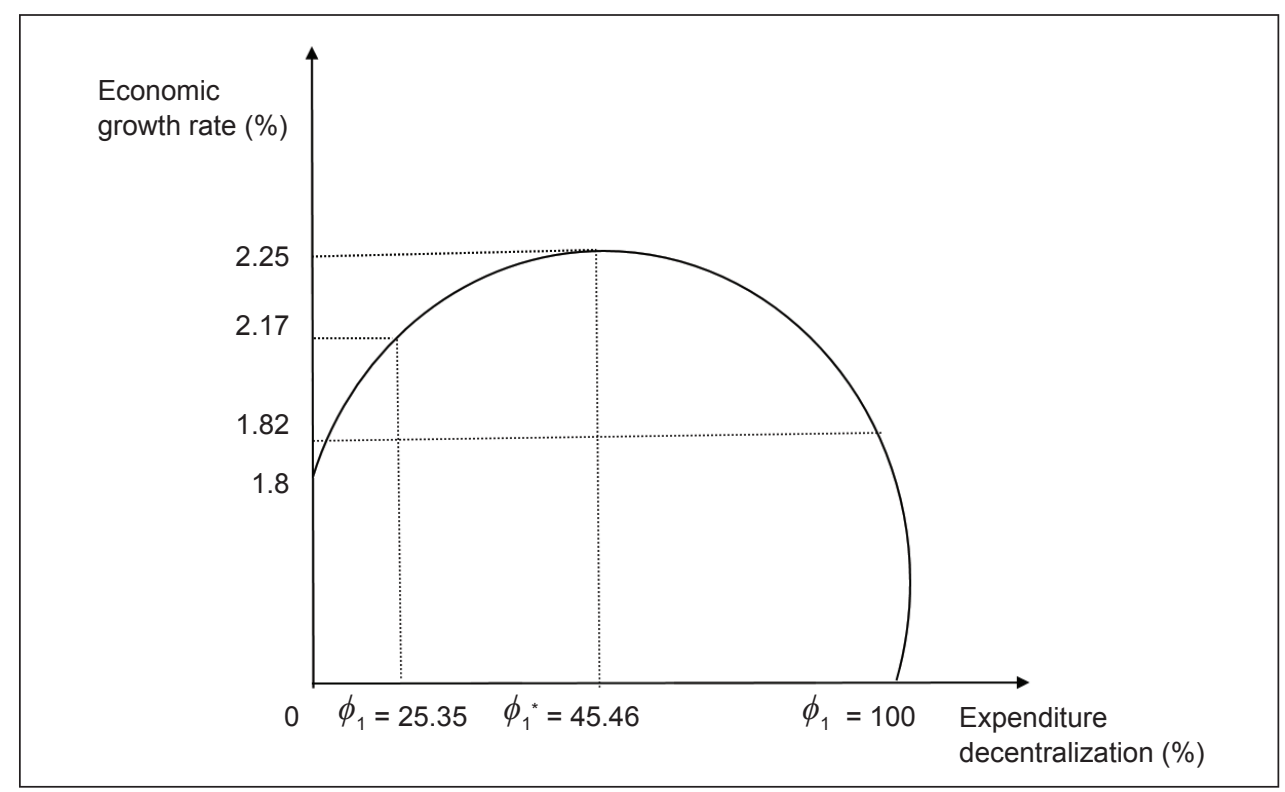

Source: Plot graph based on Equation 12, Table 1, and Table 2.

As Equation 6 and Table 2 show, the degree of revenue decentralization does not effect economic performance significantly, in contrast to Lin and Liu (2000), who presented a positive revenue decentralization-growth nexus. As Equation 2 shows, the share of sub-federal revenue relative in the total public revenue does not effect productivity in the private sector, and hence economic performance. Table 2 further indicates that corruption affects economic growth insignificantly, which contradicts with the findings in previous studies (Tanzi, 1996; Myerson, 2006). The corruption-growth nexus might thus need more scientific examinations.

\section{Conclusions}

\subsection{Policy implications}

To sum up the principal lessons we derive from the examination of the theoretical predictions and OECD country experiences presented in this study, this section briefly reviews the influences of resources allocation in the public sector on the economy and the design of public spending programmes in countries with decentralization with regard to stimulating economic growth. 
There has been considerable debate on the merits of government decentralization. While this discussion has, in the past, focussed on the efficiency of the provision of public goods, more recently greater emphasis has been placed on the role that decentralization may have in stimulating economic growth (Baskaran, Feld, and Schnellenbach, 2016; Ge et al., 2016). The provision of public goods by the subnational government through expenditure autonomy could possibly benefit residents in this and other regions and stimulate economic growth. For example, the provision of education-related public goods adds to local residents' human capital, promotes productivity, and increases outputs. Railroads and airports built in one community will provide benefits to other communities increasing investment and production. However, when publicly provided goods are less preferred by the communities or less complementary to private investments, then a higher degree of expenditure decentralization leads to less investment and slower growth. There is thus a critical level of the sub-federal provision of public goods above which economic growth is at the maximum. Efficient central government redistribution policies are required.

Fiscal decentralization is a recent phenomenon, not only in developing countries, but also many industrialized ones. Jin, Qian, and Weingast (2005) indicated that a $10 \%$ increase in expenditure decentralization was associated with a 1.6-percentage point growth in real GDP per capita over the period from 1982 to 1992 in China. In contrast, Davoodi and Zou (1998) found that a 10\% increase in expenditure decentralization was associated with a 0.8 percentage point fall in the growth of real GDP per capita over the period from 1970 to 1989 in 46 developing and developed countries.

Strong demand for reform of local government finance has led to a strong debate with regard to the provision of public goods, although there is no universal agreement on what action to take. Local tax discretion could increase local accountability, albeittaxes are seldompopular. Fortunately, based on our analytical results, revenue decentralization does not effect economic performance. Local governments can thus concentrate on the provision of local public goods. Nevertheless, the decentralization of expenditure should not politically or economically compromise subnational authorities' interests in the long run, and can be used for productive purposes. The use of fiscal resources should always endeavour to encourage the accumulation of physical capital and stimulate private investment. However, local governments may use decentralization to defer necessary reforms because voters are uncertain about what would have been achieved with a different policy (Kotsogiannis and Schwager, 2006). Our analytical results indicate that when the government uses a tax policy and the extent of sub-federal autonomy is accompanied by an appropriate level of expenditure decentralization, then countries could differentiate the supply of public infrastructure in different regions to effectively allocate fiscal resources and achieve more productive efficiency. Expenditure decentralization is associated with better economic performance, and can be used to increase sustainable economic growth. The economic growth rate could initially be an increasing function of the degree of decentralization, followed by decreasing function as decentralization continues. An optimal level of decentralization for maximizing economic growth thus exists.

An economy might benefit from faster economic growth due to trade openness along with agglomeration effects in regional areas, as seen in the European Union countries. 
Economic integration extends the market size and raises the costs of large jurisdictions because of neglecting the preference heterogeneity leading to the demand for fiscal decentralization for providing public goods locally. Appropriate decentralization in OECD countries thus could be associated with good economic performance. Public consumption expenditure is associated with slower economic growth, although such spending raises social welfare indicating a conflict between economic growth and welfare. Moreover, this conflict may lead to political or economic instability, with further negative effects on economic growth, although more empirical studies are needed to examine this issue.

\subsection{Concluding remarks}

This research aims to investigate the effects of decentralization policies on economic growth by examining the effects of revenue and expenditure decentralization on economic growth from both theoretical and country study perspectives. The analytical results reveal that revenue decentralization does not effect economic performance. With expenditure decentralization, economic growth depends crucially on the following: (i) appropriate sub-federal autonomy, (ii) trade openness, and (iii) the development status. Higher expenditure decentralization along with faster economic growth depend on the combined influences of a relatively smaller degrees of expenditure decentralization, relatively more taxation revenue, relatively more trade openness, and sustainable development stages rather than only sub-federal expansion via the supply of public goods and services. When there is a greater share of sub-federal government spending that is used to complement the spending by private capital to carry out innovation in production, a taxation policy should be proposed.

In the above analysis, this paper generalizes the results of previous works and presents some new results in the context of a unified analytical framework. This research has gone beyond orthodox analyses of country experiences at different levels of government, and opens up a discussion on the issue of decentralization and economic growth, as well as policy reforms with regard to resource allocation in the public sector.

\section{References}

Akai, N., Sakata, M. (2002). Fiscal Decentralization Contributes to Economic Growth: Evidence from State-Level Cross-Section Data for the United States. Journal of Urban Economics, 52(1), 93-108, http://doi.org/10.1016/S0094-1190(02)00018-9

Barro, R. J. (1990). Government Spending in a Simple Endogenous Growth Model. Journal of Political Economy, 98(5), 103-125, http://doi.org/10.1086/261726

Baskaran, T., Feld, L. P., Schnellenbache, J. (2016). Fiscal Federalism, Decentralization, and Economic Growth: A Meta-Analysis. Economic Inquiry, 54(3), 1445-1463, http://doi.org/10.1111/ecin.12331

Baum, C., Schaffer, M., Stillman, S. (2007). Enhanced Routines for Instrumental Variables/ Generalized Method of Moments Estimation and Testing. Stata Journal, 7(4), 465-506.

Blundell, R., Bond, S. (1998). Initial Conditions and Moment Restrictions in Dynamic Panel Data Models. Journal of Econometrics, 87(1), 11-143, http://doi.org/10.1016/ S0304-4076(98)00009-8 
Branson, J., Lovell, C. K. (2001). A Growth Maximizing Tax Structure for New Zealand. International Tax and Public Finance, 8(2), 129-146, http://doi.org/10.1023/A:101121 6618163

Brueckner, J. K. (2006). Fiscal Federalism and Economic Growth. Journal of Public Economics, 90(10-11), 2107-2120, http://doi.org/ 10.1016/j.jpubeco.2006.05.003

Canning, D., Fay, M. (1993). The Effect of Transportation Networks on Economic Growth. Department of Economics, Columbia University. Working Paper No. 653a.

Chu, A.C., Yang, C. C. (2012). Fiscal Centralization versus Decentralization: Growth and Welfare Effects of Spillovers, Leviathan Taxation, and Capital Mobility. Journal of Urban Economics, 71(2), 177-188, http://doi.org/10.1016/j.jue.2011.10.003

Davoodi, H., Zou, H. (1998). Fiscal Decentralization and Economic Growth: A CrossCountry Studies. Journal of Urban Economics, 43(2), 244-257, http://doi.org/10.1006/ juec.1997.2042

Devarajan, S., Vinaya, S., Zou, H. (1996). The Composition of Public Expenditure and Economic Growth. Journal of Monetary Economics, 37(2-3), 313-344, http://doi.org/10.1016/ S0304-3932(96)90039-2

Easterly, W., Rebelo, S. (1993). Fiscal Policy and Economic Growth: An Empirical Investigation. The National Bureau of Economic Research. Working Paper No. 4499, https://doi. org/10.3386/w4499

Edwards, S. (1993). Openness, Trade Liberalization, and Growth in Developing Countries. Journal of Economic Literature, 31(3), 1358-1393.

Freitag, M., Vatter, A. (2008). Decentralization and Fiscal Discipline in Sub-National Government: Evidence from the Swiss Federal System. Publius: The Journal of Federalism, 38(2), 272-294, http://doi.org/10.1093/publius/pjm038

Ge, X., Ye, T., Zhou, Y., Yan, G. (2016). Fiscal Centralization vs. Decentralization on Economic Growth and Welfare: An Optimal-Control Approach. Journal of Industrial and Management Optimization, 12(2), 487-504, http://doi.org/10.3934/jimo.2016.12.487

Gehlbach, S. (2007). Electoral Institutions and the National Provision of Local Public Goods. Quarterly Journal of Political Science, 2(1), 5-25, http://doi.org/10.1561/100.00005042

Hatfield, J. W. (2015). Federalism, Taxation, and Economic Growth. Journal of Urban Economics, 87(1), 114-125, http://dx.doi.org/10.1016/j.jue.2015.01.003

limi, A. (2005). Decentralization and Economic Growth Revisited: An Empirical Note. Journal of Urban Economics, 57(3), 449-461, http://doi.org/10.1016/j.jue.2004.12.007

Jin, H., Qian, Y., Weingast, B. R. (2005). Regional Decentralization and Fiscal Incentives: Federalism, Chinese Style. Journal of Public Economics, 89(9-10), 1719-1742, http://doi.org/10.1016/j.jpubeco.2004.11.008

Kotsogiannis, C., Schwager, R. (2006). Political Uncertainty and Policy Innovation. Journal of Public Economic Theory, 8(5), 779-805, http://doi.org/10.1111/j.1467-9779.2006.00288.x

Krugman, P. (1991). Increasing Returns and Economic Geography. Journal of Political Economy, 99(3), 483-499, http://doi.org/10.1086/261763

Levine, R., Renelt, D. (1992). A Sensitivity Analysis of Cross-Country Growth Regressions. American Economic Review, 82(4), 942-963.

Lin, J.Y., Liu, Z. (2000). Fiscal Decentralization and Economic Growth in China. Economic Development and Cultural Change, 49(1), 1-2, http://doi.org/10.1086/452488

Litvack, J., Ahmad, J., Bird, R. (1998). Rethinking Decentralization in Developing Countries. World Bank, Sector Studies Series, http://doi.org/10.1596/0-8213-4350-5 
Martinez-Vazquez, J., McNab, R. M. (2006). Fiscal Decentralization, Macrostability, and Growth. Department of Economics, Georgia State University, Economics Faculty Publications, Hacienda Pública Española /Revista de Economia Publica, 179(1), 25-49.

Mauro, P. (1995). Corruption and Growth. Quarterly Journal of Economics, 110(3), 681-712, http://doi.org/10.2307/2946696.

Mullen, J. K., Williams, M. (1994). Marginal Tax Rates and State Economic Growth. Regional Science and Urban Economics, 24(6), 687-705, http://doi.org/10.1016/0166-0462(94)90007-8

Myerson, R. B. (2006). Federalism and Incentives for Success of Democracy. Quarterly Journal of Political Science, 1(1), 3-23, http://doi.org/10.1561/100.00000002

Oates, W. E. (1972). Fiscal Federalism. New York: Harcourt Brace Press. ISBN 9780155274525.

Prud'homme, R. (1995). On the Dangers of Decentralization. The World Bank Research Observer, 10(2), 201-210, http://doi.org/10.1093/wbro/10.2.201

Rebelo, S. (1991). Long-Run Policy Analysis and Long-Run Growth. Journal of Political Economy, 99(3), 500-521, http://doi.org/10.1086/261764

Rose-Ackerman, S. (1975). The Economics of Corruption. Journal of Public Economics, 4(2), 187-203, http://doi.org/10.1016/0047-2727(75)90017-1

Stegarescu, D. (2009). The Effects of Economic and Political Integration on Fiscal Decentralization: Evidence from OECD Countries. Canadian Journal of Economics, 42(2), 694-718, http://doi.org/10.1111/j.1540-5982.2009.01524.x

Tanzi, V. (1996). Fiscal Federalism and Decentralization: A Review of Some Efficiency and Macroeconomic Aspects, in Bruno, M., Pleskovic, B., eds., Washington, DC: Annual World Bank Conference on Development Economics, pp. 295-316. http://doi. org/10.1596/0-8213-3280-5

ThieBen, U. (2003). Fiscal Decentralization and Economic Growth in High-Income OECD Countries. Fiscal Studies, 24(3), 237-274, http://doi.org/10.1111/j.1475-5890.2003.tb00084.x

Thornton, J. (2007). Fiscal Decentralization and Economic Growth Reconsidered. Journal of Urban Economics, 61(1), 64-70, http://doi.org/10.1016/j.jue.2006.06.001

Tiebout, C. M. (1956). A Pure Theory of Local Expenditures. Journal of Political Economy, 64(5), 416-424, http://doi.org/10.1086/257839

Turnovsky, S., Fischer, W. H. (1995). The Composition of Government Expenditure and Its Consequences for Macroeconomic Performance. Journal of Economic Dynamics and Control, 19(4), 747-786, http://doi.org/10.1016/0165-1889(94)00803-P

Uhlig, H., Yanagawa, N. (1996). Increasing the Capital Income Tax May Lead to Faster Growth. European Economic Review, 40(8), 1521-1540, http://doi. org/10.1016/0014-2921(96)00032-3

Verdier, G. (2008). What Drives Long-Term Capital Flows? A Theoretical and Empirical Investigation. Journal of International Economics, 74(1), 120-142, http://doi.org/10.1016/j. jinteco.2007.04.005

Zhang, T., Zou, H. (1998). Fiscal Decentralization, Public Expenditure and Economic Growth. Journal of Public Economics, 67(2), 221-240, http://doi.org/10.1016/ S0047-2727(97)00057-1 